\title{
DISKURSUS LITERASI ABAD 21 DI INDONESIA
}

\author{
Dipa Nugraha ${ }^{1)}$, Dian Octavianah ${ }^{2)}$ \\ ${ }^{1}$ FKIP, Universitas Muhammadiyah Surakarta \\ email: dipa.nugraha@ums.ac.id \\ ${ }^{2}$ SMA ABBS Surakarta - Al Abidin Learning Centre \\ email: doctavianah@alabidin.sch.id
}

\begin{abstract}
This study is to describe discourse on literacy in Indonesia. This study used an extensive survey of related literature on literacy which was accessed on Google Cendekia in December 2019 using "literasi abad 21" as its keyword. The analysis is descriptive qualitative. This study concludes that: First, discourse on literacy in Indonesia started with the government's National Literacy Movement in 2015. The discourse on literacy in Indonesia is based on New Vision for Education: Unlocking the Potential of Technology a framework for 21st century education from World Economic Forum and Boston Consulting Group, PISA 2015 Assessment and Analytical Framework from OECD, and 21st Century Skills Map from The Partnership for 21st Century Learning. Second, there are nineteen literacies discussed and developed within the discourse. However, environmental literacy and ecological literacy are absent, or at least lacking compared to the other nineteen literacies in the conversation. Considering environmental literacy and ecological literacy are both important for the future of Indonesia, it is suggested that Indonesian scholars in education should start talking more about these literacies in the conversation on literacy and their importance in Indonesian education.
\end{abstract}

Keywords: literacy, 21st century literacy, Indonesian literacy.

Abstrak: Penelitian ini mendeskripsikan diskursus mengenai literasi di Indonesia. Penelitian ini menggunakan survei daring dengan menggunakan Google Cendekia dengan kata kunci "literasi abad 21" yang dilakukan di bulan Desember 2019. Analisis dilakukan dengan menggunakan metode deskriptif kualitatif. Hasil dari penelitian ini ada dua. Pertama, diskursus mengenai literasi di Indonesia dimulai dengan Gerakan Literasi Nasional di tahun 2015. Diskursus mengenai literasi di Indonesia didasarkan atas tiga rujukan kerangka kerja pendidikan yaitu New Vision for Education: Unlocking the Potential of Technology dari World Economic Forum and Boston Consulting Group, PISA 2015 Assessment and Analytical Framework dari OECD, dan 21st Century Skills Map dari The Partnership for 21st Century Learning. Kedua, terdapat sembilan belas literasi yang dibicarakan dan berkembang di dalam diskursus mengenai literasi di Indonesia. Meskipun demikian, literasi lingkungan dan ekologi tidak muncul atau kurang dibicarakan. Menimbang bahwa literasi lingkungan dan ekologi penting bagi masa depan Indonesia, penelitian ini memberikan saran perlunya pembelajaran literasi ini tidak hanya mulai kencang dibicarakan tetapi juga urgensi implementasinya di dunia pendidikan di Indonesia

Kata kunci: literasi, literasi abad 21, literasi Indonesia 


\section{PENDAHULUAN}

Literasi adalah pengetahuan dan atau kompetensi dasar yang harus dimiliki seseorang sesuai konteks kebutuhan masyarakat dan perkembangan zaman. Sementara pembicaraan mengenai literasi di Barat sudah dimulai sejak lama (Arp, 1994; Keefe \& Copeland, 2011; McBride dkk., 2013), diskursus mengenai literasi sebagai sebuah istilah yang bukan sekedar tentang kemelekaksaraan di Indonesia dapat dikatakan baru dimulai ketika Menteri Pendidikan dan Kebudayaan, Anies Baswedan, mengeluarkan Permendikbud Nomor 23 Tahun 2015 yang berbicara mengenai literasi. Permendikbud ini menandai perubahan orientasi KBM dari pemberantasan buta aksara kepada KBM untuk meningkatkan kemampuan literasi penduduk (Antoro, 2017, hlm. 15). Berkat Permendikbud ini kemudian muncul Gerakan Literasi Nasional (GLN). Berkat kehadiran GLN, diskursus literasi di Indonesia mulai marak.

Di dalam GLN, meski tidak eksklusif pada kegiatan membaca namun literasi dititikberatkan kepada kegiatan membaca. Membaca adalah salah satu kegiatan yang baik dan kegiatan yang baik harus dibiasakan (Antoro, 2017, hlm. 8-9). Orientasi dari GLN adalah menumbuhkan minat baca dan melahirkan kebiasaan membaca yang berlangsung sepanjang hayat. Langkah-langkah yang dilakukan di antaranya adalah dengan memberikan stimulan imajinatif lewat buku-buku di luar buku pelajaran yang mengasah kreativitas, membangkitkan emosi, serta pelbagai hal abstrak lainnya sehingga dapat terbentuk karakter yang baik, kemudian menciptakan lingkungan baca yang menyenangkan baik di sekolah maupun di rumah. Harapannya adalah terbentuk kebiasaan membaca yang memunculkan nilai-nilai kemanusiaan dan membentuk budi pekerti yang baik, dan pelibatan publik di dalam peningkatan literasi (Antoro, 2017).

Di dalam Buku Saku Gerakan Literasi Sekolah (SGLS, 2016) disebutkan bahwa kata literasi bermakna "kemampuan dalam mengakses, memahami, dan menggunakan informasi secara cerdas." Definisi yang relatif sama juga diulang di dalam Panduan Gerakan Literasi Sekolah di Sekolah Dasar (Faizah dkk., 2016, hlm. 2). Pemaknaan yang lebih luas atas istilah literasi baru muncul di dalam buku Peta Jalan Gerakan Literasi Nasional. Di dalam buku Peta Jalan Gerakan Literasi Nasional (Ibrahim, 2017: 6) ini, literasi mempunyai 4 definisi yaitu: 1) suatu rangkaian kecakapan membaca, menulis, dan berbicara, kecakapan berhitung, dan kecakapan dalam mengakses dan menggunakan informasi, 2) praktik sosial yang penerapannya dipengaruhi oleh konteks, 3) proses pembelajaran dengan kegiatan membaca dan menulis sebagai medium untuk merenungkan, menyelidik, menanyakan, dan mengkritisi ilmu dan gagasan yang dipelajari, dan 4) teks yang bervariasi menurut subjek, genre, dan tingkat kompleksitas bahasa.

Sementara itu di dalam Kamus Bahasa Indonesia (Sugono dkk., 2008) yang diterbitkan oleh Pusat Bahasa Departemen Pendidikan Nasional tidak terdapati lema literasi. Kata literasi kemudian muncul di KBBI versi daring berdasarkan laporan pemerhati bahasa Ivan Lanin di bulan Oktober 2017. Literasi berdasarkan tangkapan layar yang dirilis lewat akun twitter Ivan Lanin (2017) mengandung dua makna yaitu 1) kemampuan menulis dan membaca dan 2) pengetahuan atau keterampilan dalam bidang atau aktivitas tertentu. Berdasarkan pencarian di KBBI Daring terkini, kata literasi kini mempunyai tiga arti yaitu: 1) kemampuan menulis dan membaca, 2) pengetahuan atau keterampilan dalam bidang atau aktivitas tertentu, dan 3) kemampuan individu dalam mengolah informasi dan pengetahuan untuk kecakapan hidup. Ini berarti bahwa nomor 3 baru ditambahkan kemudian. Ini menjadi bukti bahwa literasi adalah istilah yang baru di dalam bahasa Indonesia.

Penelitian mengenai istilah literasi dari masa ke masa di Indonesia sebelumnya sudah dilakukan oleh Damayantie (2015). Di dalam tulisannya, Damayantie membahas literasi lebih dalam konteks kemampuan membaca, menulis, dan berpikir kritis. Ia tidak secara spesifik merunut awal mula penggunaan istilah 
literasi di Indonesia, bagaimana istilah ini kemudian menjadi topik yang dinamis, dan memunculkan bermacam istilah yang tumpang tindih mengekor kata literasi. Tulisan ini hendak membicarakan diskursus mengenai literasi di Indonesia dan urgensinya di dalam pendidikan di Indonesia. Karena pemicu diskursus literasi di Indonesia adalah kehadiran program GLN sebagaimana telah disebutkan sebelumnya, maka di dalam tulisan ini tentu akan dibandingkan peta jalan GLN dengan visi World Economic Forum yang berkolaborasi dengan The Boston Consulting Group (WEF \& BCG) mengenai keterampilan yang diperlukan di abad 21 yang tercantum di dalam New Vision for Education: Unlocking the Potential of Technology. Kemudian dari pembandingan tersebut akan dibandingkan bagaimana para akademisi Indonesia turut memperkaya wacana mengenai literasi di Indonesia yang mungkin berguna di dalam mengembangkan peta jalan GLN.

\section{METODE PENELITIAN}

Penelitian ini menggunakan metode survei daring untuk mendapatkan artikel ilmiah karya akademisi Indonesia berkenaan dengan pembicaraan tentang literasi di Indonesia. Survei dilakukan dengan mesin pencari Google Cendekia yang dilangsungkan di bulan Desember 2019 dengan kata kunci "literasi abad 21."

Artikel yang dipilih untuk dianalisis di dalam pembicaraan diskursif mengenai literasi adalah artikel yang terbit di dalam jurnal ilmiah atau prosiding atau makalah yang disampaikan di dalam temu ilmiah di Indonesia. Jumlah artikel yang dipilih hanya akan dibatasi sebanyak 10 buah. Metode yang dipakai di dalam penelitian ini adalah replikasi dan modifikasi dari penelitian yang sebelumnya dilakukan oleh David Crusoe (2016) di dalam penelitian survei daringnya mengenai diskursus literasi data.

Crusoe (2016) melakukan penelitian survei daring yang dilakukan melalui laman pengindeks artikel jurnal melalui Academic Search Complete, Google Scholar, JSTOR hingga Desember 2015. Dengan kata kunci tertentu seperti "data literacy," Crusoe mengumpulkan 16 artikel jurnal yang berbicara mengenai literasi data. Sedangkan validitas data diperoleh dengan triangulasi sumber data melalui survei daring melalui mesin pencari Google dalam rangka mencari artikel-artikel jurnal dan berita di internet yang relevan dengan kata kunci.

Seperti yang dilakukan oleh Crusoe, penelitian ini juga menggunakan trianggulasi sumber data untuk memperoleh validitas data. Trianggulasi sumber data akan memberikan pemahaman lebih dalam akan konteks pembicaraan dan juga meningkatkan derajat kepercayaan dari temuan (Carter dkk., 2014). Trianggulasi sumber data dalam penelitian ini dilakukan dengan menggunakan mesin pencari Google untuk melakukan survei daring atas berita dari kanal berita daring atau laman resmi pemerintah yang membahas literasi di Indonesia. Analisis deskriptif kualitatif dilakukan terhadap data yang diperoleh untuk memberikan gambaran mengenai diskursus literasi di Indonesia. Langkahlangkah analisis deskriptif kualitatif dengan mengikuti Flick (2014, hlm. 5-6) maka bakal melibatkan aktivitas pendeskripsian, pembandingan menuju penjelasan kepada fenomena yang diteliti atas data yang ada.

\section{HASIL DAN PEMBAHASAN}

Tidak bisa dipungkiri bahwa diskursus literasi di Indonesia dimulai dari kehadiran Gerakan Literasi Nasional (GLN). GLN di dalam beberapa buku panduannya berulang kali merujuk kepada New Vision for Education dari WEF \& BCG dan istilah literasi kemudian di dalam diskursusnya melekat secara konsisten dengan jawaban atas kebutuhan dan tantangan abad 21. Oleh sebab itulah pembahasan mengenai diskursus literasi abad 21 di Indonesia dimulai dari GLN, kemudian New Vision for Education, baru kemudian kita bandingkan dengan pembicaraan mengenai literasi di dalam 10 artikel akademisi Indonesia yang didapat lewat survei daring melalui Google Cendekia.

\section{Gerakan Literasi Nasional (GLN)}

Konsep pembelajaran kepada siswa di dalam menghadapi abad 21 di dalam 
GLN menampilkan adaptasi dari diagram New Vision for Education dengan menampilkan tiga kategori yang sama dengan New Vision for Education dari WEF \& BCG yaitu: literasi dasar, kompetensi, dan karakter (Ibrahim dkk., 2017, hlm. 5).

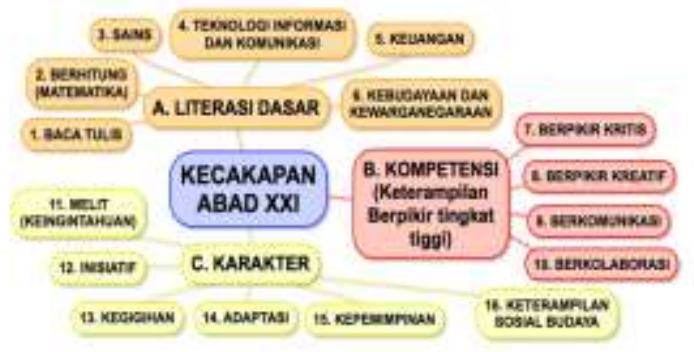

16 Kecakapan Abad 21 Adaptasi dari WEF \& BCG (Laksono dkk., 2018, hlm. 1)

Dalam kategori karakter, apa yang ada di dalam konsep New Vision for Education dari WEF \& BCG sebagai enam Character Qualities dimodifikasi di dalam GLN menjadi lima nilai utama karakter dan berkelindan dengan Gerakan Penguatan Pendidikan Karakter (Laksono dkk., 2018, hlm. 2). Kelima nilai utama karakter tersebut adalah: religius, nasionalis, mandiri, gotong royong, integritas (Hendarman dkk., 2017, hlm. 8-9).

Berbeda dengan New Vision for Education yang menekankan pada lingkungan yang padat teknologi informasi dan jaringan internet di dalam mengusung pembelajaran dan pengembangan 16 keterampilan yang diperlukan di abad 21, orientasi GLN adalah "penyediaan bahan bacaan dan peningkatan minat baca anak sebagai bagian penting dari penumbuhan budi pekerti [sehingga kemudian] literasi dasar berikutnya (numerasi, sains, digital, finansial, serta budaya dan kewargaan) dapat ditumbuhkembangkan" (Ibrahim, 2017, hlm. v).

Penempatan teknologi dalam GLN diletakkan bukan pada bagaimana teknologi dihadirkan dalam ejawantah lingkungan yang padat teknologi informasi dan jaringan internet dalam proses pembelajaran pengembangan 16 keterampilan sebagaimana didapati dalam New Vision for Education namun pada bahan bacaan literasi digital dan "meningkatnya sikap positif, bijak, cermat, dan tepat dalam menggunakan dan mengelola media digital." Bagian yang menyatakan bahwa literasi digital diharap mampu meningkatkan "kemampuan berfikir kritis, kreatif, dan inovatif dalam menggunakan media digital dalam kehidupan sehari-hari" (Ibrahim, 2017, hlm. 25) baru diarahkan kepada penggunaan "teknologi digital dan alat-alat komunikasi atau jaringan untuk menemukan, mengevaluasi, menggunakan, mengelola, dan membuat informasi secara bijak dan kreatif ... [yang mendukung] program produktif, [pengetahuan akan] keamanan dan kerahasiaan, gaya hidup digital, dan kewirausahaan" (Ibrahim, 2017, hlm. 32). Berbeda dengan New Vision for Education yang menyadari akan kehadiran "rapidly evolving, technology-mediated world" sehingga istilah Unlocking the Potential of Technology dipakai sebagai subjudul dari visi baru mengenai pendidikan, GLN menitikberatkan kehadiran teknologi digital sebagai portal informasi yang harus dimanfaatkan secara bijak. Jadi sebenarnya ada diskrepansi dari perujukan pembelajaran pengembangan 16 keterampilan yang diperlukan di abad 21 di dalam GLN kepada New Vision for Education dari WEF \& BCG.

Literasi di dalam modul GLN yang berjudul Strategi Literasi dalam Pembelajaran disebutkan menjadi bagian dari 16 keterampilan yang diperlukan di abad 21. Keterampilan yang berjumlah 16 ini dipecah menjadi 3 kategori yaitu 6 literasi dasar, 4 kompetensi, dan 6 karakter dengan merujuk pada World Economic Forum 2015. Enam literasi (atau literasi dasar) tersebut adalah literasi baca tulis, literasi berhitung, literasi sains, literasi TIK, literasi keuangan, dan literasi kebudayaan \& kewarganegaraan. Dari keenam literasi dasar ini, kemudian bisa ditambahkan lagi empat literasi yaitu literasi kesehatan (health literacy), literasi keselamatan (road safety literacy, disaster mitigation literacy), literasi kriminal (crime prevention literacy), dan literasi gestur (body language literacy) (Laksono dkk., 2018: 1-2). Dari sepuluh literasi yang diperkenalkan di dalam payung GLN tersebut, masih ditambah lagi dengan literasi perpustakaan, literasi media, dan literasi visual di dalam buku Panduan 
Gerakan Literasi Sekolah di Sekolah Menengah Atas (Sutrianto, 2016).

Untuk kategori karakter, lima nilai utama diajukan yaitu: religius, nasionalis, mandiri, gotong royong, dan integritas (Laksono dkk., 2018). Untuk kategori kompetensi, modul Strategi Literasi dalam Pembelajaran mengindikasikan bahwa 4 kompetensi yang ada (berpikir kritis, berpikir kreatif, berkomunikasi, berkolaborasi) dapat dirangkum dengan satu istilah yaitu keterampilan berpikir tingkat tinggi (Laksono dkk., 2018, hlm. 12). Enam literasi atau literasi dasar yang ada di dalam modul Strategi Literasi dalam Pembelajaran mengalami sedikit perubahan bila dibandingkan dengan apa yang sebelumnya termaktub di dalam buku Peta Jalan Gerakan Literasi Nasional (lih. Ibrahim, 2017, hlm. 7-8).

Sebelumnya, literasi dasar disebut dengan dimensi literasi, literasi TIK sebelumnya disebut sebagai literasi digital, kemudian literasi kebudayaan \& kewarganegaraan sebelumnya disebut dengan literasi budaya \& kewargaan. Meskipun demikian, istilah yang dipakai di dalam situs GLN mengikuti istilah-istilah yang dipakai di dalam Peta Jalan Gerakan Literasi Nasional dengan penggunaan literasi dasar, literasi digital, dan literasi budaya \& kewargaan.

Sementara itu, di dalam Modul dan Pedoman Pelatihan Fasilitator Gerakan Literasi Nasional disebutkan bahwa penguasaan 6 literasi dasar adalah sesuatu yang "disepakati oleh World Economic Forum pada tahun 2015." Meski kemudian di halaman lainnya terdapat redaksi yang berbeda bahwa literasi dasar adalah salah satu dari tiga "gambaran keterampilan abad ke-21 yang sebaiknya dimiliki oleh seluruh bangsa di dunia" yang diberikan oleh World Economic Forum di tahun 2015. Dua keterampilan lainnya adalah kompetensi dan karakter (Chodidjah dkk., 2017, hlm. v, 2).

Sehingga dapatlah dikatakan bahwa istilah literasi bukan hanya istilah yang baru muncul namun juga kemunculannya terkait dengan program GLN yang diluncurkan oleh pemerintah di tahun 2015. Awalnya fokus GLN kepada peningkatan minat dan aktivitas membaca sehingga tercipta pribadi yang tidak hanya luas pengetahuan tetapi juga tercipta pribadi yang baik akhlaknya serta menjadi pebelajar sepanjang hayat di masa Anies Baswedan kemudian berlanjut kepada program yang orientasinya pada pembekalan warga negara di dalam beradaptasi dengan abad 21 di masa Muhadjir Effendy. Peta jalan GLN dari rujukan yang ada terlihat bahwa keterampilan abad 21 yang digaungkan diakui mengekor pada visi World Economic Forum di tahun 2015.

Di dalam perkembangan diskursus mengenai gerakan literasi nasional, enam literasi dasar plus empat literasi di dalam Strategi Literasi dalam Pembelajaran (Laksono dkk., 2018, hlm. 1-2) dan tiga literasi tambahan lainnya yang tercantum dalam Panduan Gerakan Literasi Sekolah di Sekolah Menengah Atas (Sutrianto, 2016, hlm. 5-6) disusul dengan penambahan dua tambahan literasi baru dalam menghadapi era revolusi industri 4.0 yang dikemukakan oleh Menristekdikti Mohamad Nasir pada saat memberikan kuliah umum di bulan April 2019 di Universitas Jember. Dua literasi tambahan ini yaitu literasi data dan literasi manusia (Meilanova, 2019). Literasi manusia ini kadang disebut dengan istilah literasi humanitas (Abdullah, 2019).

Kemudian masih di tahun yang sama, Badan Pengkajian dan Penerapan Teknologi (BPPT) di dalam siaran persnya di bulan September 2019 menggaungkan urgensi kebutuhan akan literasi baru di dalam gerakan literasi nasional. Literasi baru seperti yang disampaikan oleh Menristekdikti sebelumnya (literasi data, literasi teknologi, literasi manusia) dengan satu tambahan yakni literasi bahasa (Humas HMP BPPT, 2019).

\section{New Vision for Education WEF \& BCG}

Berdasarkan ulasan Soffel (2016) yang diterbitkan di dalam situs resmi World Economic Forum, jurang pemisah antara keterampilan yang selama ini dipelajari orang dengan keterampilan yang sebenarnya dibutuhkan kian melebar. Lulusan sekolah yang berhasil berkompetisi di dunia kerja masa kini adalah mereka yang mampu berkolaborasi, berkomunikasi, 
dan memecahkan masalah. Berdasarkan penelitian, keterampilan seperti ini bisa dikembangkan lewat pembelajaran sosial dan emosional (social and emotional learning atau SEL) dan akan berhasil jika dikombinasikan dengan pembelajaran literasi dasar. Luaran dari pembelajaran seperti ini diyakini akan memberikan bekal bagi siswa untuk mampu menghadapi abad 21. Oleh sebab itulah maka pengembangan keterampilan sosial dan emosional bersama pemantapan keterampilan dasar yang mengikuti kebutuhan zaman diharap dapat diterapkan di sistem pendidikan manapun di seluruh dunia.

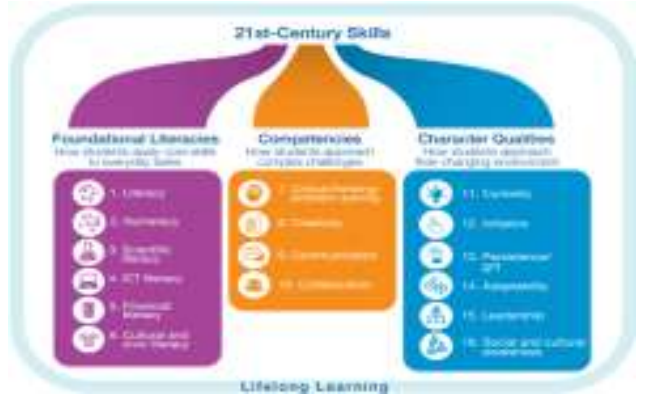

16 Keterampilan Abad 21 (WEF \& BCG, 2015, hlm. 3)

Di era ketika teknologi berkembang begitu cepat dan mengubah lanskap dunia kerja, pendidikan harus juga beradaptasi untuk mempersiapkan siswa yang mampu menjawab tantangan-tantangan baru. Masuknya teknologi informasi dan jaringan internet ke dalam proses belajar mengajar adalah sebagian tahapan di dalam memperkenalkan teknologi dan lingkungan baru yang terikat dengannya kepada siswa. Teknologi dihadirkan dalam proses belajar mengajar bukan sekedar untuk mengenalkan teknologi tetapi juga untuk membantu pengembangan kompetensikompetensi dan peningkatan kualitas karakter siswa. Sebab dunia kerja yang akan dimasuki oleh siswa kelak bukan sebuah dunia yang membutuhkan orang yang bisa memakai teknologi saja namun pada kebutuhan akan kemampuan untuk berinovasi, menganalisis informasi, termasuk memecahkan masalah di dalam lingkungan yang padat teknologi.

Konsep pembelajaran dalam New Vision for Education: Unlocking the Potential of Technology (2015) bercirikan padat teknologi. Tentu saja tujuannya adalah membekali para siswa dengan literasi teknologi dan membiasakan mereka berkembang di dalam lingkungan padat teknologi. Sebagai contoh, literasi baca tulis dikembangkan lewat aplikasi Read 180 dan literasi numerasi dikembangkan dengan aplikasi Dreambox (WEF \& BCG, 2015). Untuk meningkatkan keterampilan berkomunikasi dan berkolaborasi digunakan perangkat digital atau aplikasi semisal Google Apps for Education, OneNote, Facebook, dan Ponder (WEF \& BCG, 2015). Untuk pembentukan karakter seperti memiliki rasa ingin tahu, tidak pantang menyerah serta kemampuan berpikir kritis kepada siswa dilakukan dengan menggunakan aplikasi gim SimCityEDU: Pollution Challenge! sementara kompetensi berpikir kreatif, kemampuan memecahkan masalah, dan keterampilan berkolaborasi dilakukan lewat platform Tynker (WEF \& BCG, 2015). Dari sinilah bisa didapati perbedaan literasi abad 21 GLN dengan apa yang dibicarakan di dalam implementasi konsep New Vision for Education.

\section{Diskursus Akademisi Indonesia Mengenai Literasi}

Dari hasil penelusuran dengan mengetikkan kata "literasi abad 21" (tanpa tanda kutip) ke dalam kotak pencarian Google Cendekia, didapatkan artikel pertama adalah tulisan Yuliati (2017) dengan judul "Literasi Sains dalam Pembelajaran IPA" yang terbit di Jurnal Cakrawala Pendas. Di dalam tulisannya ini, Yuliati memaparkan tentang peran penting literasi sains yang sifatnya bukan hanya pada penguasaan materi sains tetapi juga "penguasaan kecakapan hidup, kemampuan berpikir dan kemampuan dalam melakukan proses-proses sains pada kehidupan nyata peserta didik" (Yuliati, 2017, hlm. 27). Ia mengajukan Pembelajaran Berbasis Masalah (Problembased Learning) dan pembelajaran yang berorientasi pada siswa aktif (Active Learning). Teknologi dipakai di dalam pembelajaran hanya dalam konteks yang mendukung "penguasaan literasi sains dan kompetensi abad 21" (Yuliati, 2017, hlm. 27) tanpa ada penjelasan secara detail. 
Sedangkan kompetensi abad 21 dalam literasi sains di dalam artikel ini adalah "kemampuan untuk memahami sains, mengkomunikasikan sains (lisan maupun tulisan), serta menerapkan kemampuan sains untuk memecahkan masalah sehingga memiliki sikap dan kepekaan yang tinggi terhadap diri dan lingkungannya dalam mengambil keputusan berdasarkan pertimbangan-pertimbangan sains" (Yuliati, 2017, hlm. 22).

Artikel kedua berjudul "Transformasi pendidikan abad 21 sebagai tuntutan pengembangan sumber daya manusia di era global" yang ditulis oleh Wijaya, Sudjimat, $\&$ Nyoto (2016). Di dalam artikel ini, para penulis merujuk kepada kerangka kerja pembelajaran abad 21 yang dikeluarkan oleh Partnership for 21st Century Learning atau P21. Di dalam adaptasi atas kerangka kerja pembelajaran ini, ada tiga subjek inti dan tiga kategori keterampilan menghadapi abad 21. Tiga subjek intinya adalah literasi baca tulis, literasi numerasi, dan literasi ICT. Sedangkan untuk keterampilan yang harus dibekalkan kepada anak didik adalah: 1.) keterampilan hidup dan berkarir (life and career skills), 2.) keterampilan belajar dan berinovasi (learning and innovation skills), dan 3.) keterampilan teknologi dan media informasi (information media and technology skills). Ketiga kategori keterampilan ini kemudian dapat dijabarkan untuk keterampilan hidup dan berkarir meliputi fleksibilitas, adaptabilitas, keterampilan berinisiatif, keterampilan memanajemen diri sendiri, keterampilan berinteraksi sosial dalam konteks antarbudaya, produktif, akuntabel, memiliki keterampilan memimpin dan bertanggung jawab. Selanjutnya untuk keterampilan belajar dan berinovasi meliputi keterampilan berpikir kritis dan mengatasi masalah, keterampilan berkomunikasi dan berkolaborasi, kreatif, dan inovatif. Untuk keterampilan teknologi dan media informasi, Wijaya, Sudjimat, \& Nyoto (2016) menyebutkan tiga jenis literasi lainnya yaitu literasi informasi, literasi media, dan literasi ICT (teknologi informasi dan komunikasi).

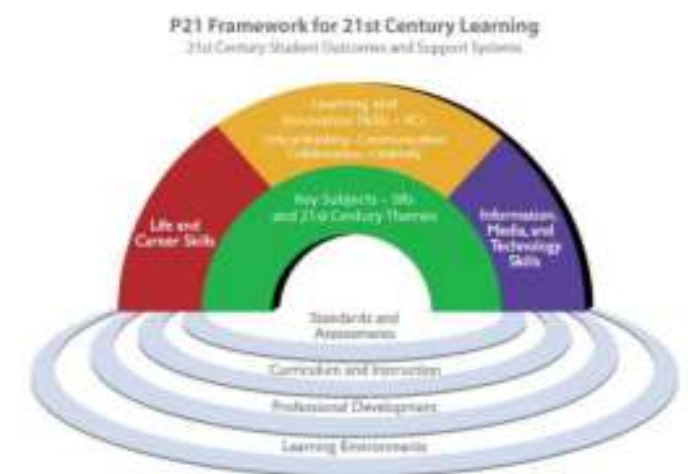

Kerangka Kerja Pembelajaran untuk Abad 21 menurut Partnership for $21^{\text {st }}$ Century Learning (P21, 2015, hlm. 1)

Tulisan ilmiah berikutnya yang muncul dari survei pustaka daring dengan Google Cendekia adalah makalah berjudul "Mengoptimalkan aspek literasi dalam pembelajaran kimia abad 21" karya Sri Rahayu (2017). Di dalam makalah ini, Rahayu (2017) merujuk kepada kategori keterampilan yang diperlukan di abad 21 menurut WEF \& BCG dan kerangka kerja literasi PISA / OECD tahun 2015. Adaptasi Rahayu (2017, hlm. 7-8) menghadirkan literasi sains dalam empat aspek yaitu konteks, pengetahuan (knowledge), kompetensi, dan sikap (attitude). Di dalam proses pembelajaran literasi sains, ia menyodorkan pembelajaran yang memiliki pendekatan Inkuiri-Eksplisit Reflektif (explicit and reflective inquiry-oriented learning). Sementara PISA / OECD tahun 2015 menekankan pada dua hal yaitu science dan science-based technology (OECD, 2017, hlm. 20), Rahayu di dalam tulisannya tidak membahas science-based technology di dalam makalahnya. Karena fokus makalah Rahayu terletak pada literasi sains maka dapat dipahami tidak disebutkannya jenis-jenis literasi (literasi baca, literasi matematika, literasi sains, literasi finansial) dan kompetensi (keterampilan pemecahan masalah secara kolaboratif baik dunia riil maupun virtual) di dalam PISA / OECD tahun 2015 (OECD, 2017, hlm. 132-133).

Di dalam tulisan ilmiah keempat karya Arohman, Saefudin, \& Priyandoko (2016) yang muncul dari hasil temuan Google Cendekia, pembicaraannya terbatas hanya pada literasi sains. Di dalam makalah 
ini Arohman, Saefudin, \& Priyandoko (2016, hlm. 90) mendefinisikan literasi sains sebagai kemampuan untuk "menggunakan pengetahuan ilmiah, mengidentifikasi pertanyaan dan menarik kesimpulan berdasarkan fakta dan data untuk memahami alam semesta dan membuat keputusan dari perubahan yang terjadi karena aktivitas manusia."

Makalah selanjutnya adalah makalah yang berbicara mengenai literasi matematika. Di dalam makalah yang berjudul "Literasi Matematika: Apa, Mengapa, dan Bagaimana" ini, Sari (2015, hlm.715) berbicara tentang pendapat De Lange terkait literasi matematika. Literasi matematika adalah "leburan dari dari spatial literacy, numeracy literacy, dan quantitative literacy ... [yang] mencakup semua konsep, prosedur, fakta dan alat matematika baik dari sisi perhitungan, angka maupun keruangan."

Literasi matematika adalah literasi yang sangat penting di dalam kehidupan manusia sebab akan membuat seseorang mampu berpikir secara kalkulatif, numeris, dan spasial dalam kehidupan sehari-hari. Metode pembelajaran yang mungkin diterapkan di dalam pembelajaran literasi matematika menurut Sari (2015) adalah realistik matematika (Realistic Mathematic Education), pembelajaran berbasis masalah (Problem-based Learning), pembelajaran memecahkan masalah (Problem-solving Learning), dan pendekatan kontekstual (contextual teaching \& learning).

Tulisan berikutnya adalah artikel dari Nopilda dan Kristiawan yang berjudul "Gerakan Literasi Sekolah Berbasis Pembelajaran Multiliterasi Sebuah Paradigma Pendidikan Abad Ke-21" (2018). Di dalam artikel ini, Nopilda dan Kristiawan (2018) menyebut literasi yang diperlukan untuk abad 21 telah bergeser kepada kebutuhan pembelajaran multiliterasi. Pembelajaran ini melibatkan proses literasi yang multikonteks, multimedia, dan multibudaya. Pembelajaran multiliterasi yang diajukan di dalam artikel ini mengarahkan siswa untuk membaca, menulis, dan berbahasa lisan yang melibatkan 3 tahapan yaitu pembiasaan (penumbuhan minat dan motivasi), pengembangan, dan pembelajaran (simulasi, praktik, karya).

Selain literasi dasar baca tulis, artikel karya Nopilda dan Kristiawan (2018) juga berbicara tentang pembelajaran literasi media dan literasi visual. Literasi media didefinisikan sebagai "kemampuan untuk mengetahui berbagai bentuk media yang berbeda seperti media cetak, media elektronik dan media digital, dan memahami tujuan penggunaanya" sedangkan literasi visual adalah "pemahaman tingkat lanjut antara literasi media dan literasi teknologi dimana mengembangkan kebutuhan belajar dengan memanfaatkan materi visual dan audiovisual secara kritis." Kedua definisi atas dua jenis literasi ini dirujukkan kepada buku Panduan Gerakan Literasi Sekolah di Sekolah Menengah Atas (2016) terbitan Kemendikbud. Pembelajaran literasi yang dibahas oleh Nopilda dan Kristiawan (2018, hlm. 230) ini telah diterapkan di SMK Negeri 1 Suak Tapeh, Kabupaten Banyuasin, Sumatera Selatan menghasilkan siswa yang memiliki minat baca tinggi, mampu membaca kritis, memiliki keterampilan berkomunikasi yang baik, berbudi pekerti yang baik, memiliki sifat kreatif, inovatif, dan produktif.

Tulisan ketujuh adalah makalah yang ditulis oleh Mohamad Amin yang berjudul "Sadar Berprofesi Guru Sains, Sadar Literasi: Tantangan Guru Di Abad 21" (2017). Di dalam makalahnya ini, Amin berbicara mengenai literasi sains dan urgensi guru untuk meningkatkan kegiatan berliterasi. Konten dari makalah ini sebagian besarnya sudah dibahas di dalam tulisan ilmiah keempat karya Arohman, Saefudin, \& Priyandoko (2016).

Di dalam artikel yang berjudul "Penerapan Project Based Learning untuk Melatih Kemampuan Literasi Tumbuhan Abad 21 pada Siswa SMA," Rizkamariana, Diana, \& Wulan (2019) disebutkan literasi sains yang bisa dipecah-pecah menjadi literasi yang lebih khusus. Mereka menyebut bahwa literasi sains dapat dipecah menjadi beberapa literasi seperti literasi biologi dan literasi biologi dapat dipecah lagi menjadi beberapa literasi seperti literasi tumbuhan. Literasi menurut 
artikel ini secara implisit terdefinisikan sebagai pengetahuan pada bidang tertentu. Pemaknaan istilah literasi seperti ini sesuai dengan definisi kedua dari lema literasi di dalam KBBI Daring.

Tulisan ilmiah kesembilan adalah sebuah makalah berjudul "Peran Biologi dan Pendidikan Biologi dalam Menyiapkan Generasi Unggul dan Berdaya Saing Global." Penulis makalah ini, Permana (2015), menjelaskan bahwa abad 21 memberikan tantangan kepada guru untuk dapat menyelenggarakan pembelajaran yang mampu meningkatkan kreativitas siswa, keterampilan informasi dan komunikasi, keterampilan berpikir dan memecahkan masalah, keterampilan interpersonal dan mengatur diri sendiri sebagai adaptasi dari kerangka kerja pembelajaran dari P21. Ia kemudian mengusung pembelajaran campuran (blended learning) dengan memadukan pembelajaran tatap muka kelas (face to face) dengan pembelajaran elektronik ( $e$ learning). Media yang dipilih Permana di dalam pembelajaran campuran yang dilakukannya adalah Facebook. Lewat Facebook diadakan diskusi daring dengan materi yang berasal dari buku ajar yang disusun untuk pembelajaran campuran. Berdasarkan penelitian yang dilakukannya, pembelajaran campuran dengan Facebook memberikan pengalaman literasi digital selain meningkatkan kemampuan komunikasi siswa.

Tulisan ilmiah terakhir atau kesepuluh adalah makalah karya Dinni yang berjudul "HOTS (High Order Thinking Skills) dan Kaitannya dengan Kemampuan Literasi Matematika" (2018). Di dalam makalah ini ditunjukkan bagaimana tingkat literasi matematika menurut PISA yang mencantumkan level tertingginya sebagai kemampuan siswa "menggunakan penalarannya dalam menyelesaikan masalah matematis, dapat membuat generalisasi, merumuskan serta mengkomunikasikan hasil temuannya" dalam banyak segi sejalan dengan model HOTS yang menampilkan level tertinggi C6 (mencipta) yang terdeskripsikan sebagai "kemampuan memadukan unsur-unsur menjadi sesuatu bentuk baru yang utuh dan luas, atau membuat sesuatu yang orisinil" (Dinni, 2018, hlm. 174). Oleh sebab itulah maka penguasaan akan HOTS menurut Dinni bisa diimplementasikan di dalam pembelajaran literasi matematika.

Tampak bahwa diskursus mengenai literasi untuk abad 21 di Indonesia bertemali dengan New Vision for Education dari WEF \& BCG, Assessment and Analytical Framework dari OECD / PISA, dan P21 Framework Definitions dari The Partnership for 21st Century Learning. Meski sering dirujuk sebab menjadi model dari pengembangan peta jalan GLN di Indonesia, New Vision for Education dari WEF \& BCG konteksnya adalah situasi pembelajaran yang padat teknologi dalam technology-mediated world sebagaimana juga dengan kerangka kerja pembelajaran abad 21 dari OECD / PISA dan P21. Di dalam GLN dan sepuluh tulisan ilmiah yang didapat lewat survei pustaka daring melalui Google Cendekia, ada perbedaan konsep implementasi pembelajaran literasi abad 21. Ini bisa terjadi karena adanya adaptasi kerangka kerja pembelajaran yang disesuaikan dengan konteks infrastruktur teknologi dan media pembelajaran Indonesia.

Usaha untuk mewujudkan praktik New Vision for Education yang Unlocking the Potential of Technology yang padat teknologi di dalam konteks Indonesia tidaklah mudah. Misalnya untuk proyeksi program pemerintah di tahun 2023 terkait dengan infrastruktur TIK dan akses internet di dunia pendidikan, kebutuhan dengan fasilitas yang bisa diberikan oleh pemerintah Indonesia kepada sekolahsekolah yang membutuhkan dengan hanya 4 komputer jinjing, 1 LCD proyektor, 1 perangkat akses internet, dan satu diska keras eksternal (Harususilo, 2018) masih jauh dari kondisi ideal dalam rangka implementasi konsep pendidikan literasi yang sesuai dengan ancangan kerangka kerja WEF \& BCG. Oleh sebab itulah, adaptasi konsep pembelajaran literasi abad 21 dalam kerangka kerja WEF \& BCG kemudian terpaksa mengalami adaptasi mengikuti kondisi infrastruktur di Indonesia. 
Meski demikian, model kerangka kerja pembelajaran menghadapi abad 21 yang membagi fokus pada tiga domain yaitu literasi, kompetensi, dan karakter sebenarnya memberikan peta jalan yang jelas kepada arah pendidikan di Indonesia. Apalagi domain (kualitas) karakter di dalam New Vision for Education bisa berkesesuaian dengan program Pendidikan Karakter yang sebelumnya sudah berjalan di Indonesia.

Beberapa literasi yang ada sudah terjelaskan definisinya dari beberapa survei pustaka di atas. Jenis literasi yang mengemuka di dalam diskursus mengenai literasi abad 21 di Indonesia ditemukan ada sembilan belas buah yaitu: 1. literasi baca tulis (literacy), 2. literasi numerasi (numerical literacy), 3. literasi sains (scientific literacy), 4. Literasi TIK (ICT literacy), 5. literasi keuangan (financial literacy), 6. literasi budaya \& kewargaan (cultural and civic literacy), 7. literasi kesehatan (health literacy), 8. literasi keselamatan (road safety, disaster mitigation literacy), 9. literasi kriminal (crime risk literacy), 10. literasi gestur (body language literacy), 11. literasi perpustakaan (library literacy), 12. literasi media (media literacy), 13. literasi digital (digital literacy), 14. literasi informasi (information literacy), 15. literasi visual (visual literacy), 16. literasi data (data literacy), 17. literasi manusia (human literacy), 18. literasi bahasa (language literacy), 19. literasi matematika (mathematical literacy).

Beberapa literasi yang dibicarakan di dalam buku atau modul GLN dan artikel yang didapati lewat survei daring melalui Google Cendekia namun belum mempunyai kejelasan ranahnya atau saling bertumpang tindih pengkategorisasiannya akan diberikan penjelasannya berikut ini.

Pertama: Literasi kesehatan atau health literacy adalah tingkat di mana seseorang memiliki kapasitas atau kemampuan untuk memperoleh, memproses, dan memahami informasi dasar mengenai kesehatan dan layanan kesehatan sehingga ia mampu membuat keputusan yang berkenaan dengan isu kesehatan. Definisi ini diberikan oleh Ratzan dan
Parker dalam buku National Library of Medicine Current Bibliographies in Medicine: Health Literacy (2000) akan tetapi definisi ini dikutip dan mendapatkan penjelasan tambahan yang sangat lengkap di dalam artikel yang ditulis oleh NielsenBohlman, Panzer, \& Kindig (2004) dengan judul "What is Health Literacy."

Kedua: Literasi keselamatan dari bencana atau mitigasi bencana (disaster mitigation literacy/disaster risk-reduction literacy) adalah pengetahuan yang menghubungkan kewaspadaan, pengetahuan, dan teknik serta kemampuan untuk dapat waspada akan bahaya atau risiko, dan informasi mengenai aspek-aspek bencana alam yang membuat seseorang mempunyai rujukan di dalam mengambil keputusan di dalam usaha penyelamatan diri saat bencana alam terjadi (Kanbara dkk., 2016).

Ketiga: Literasi pencegahan tindak kejahatan (crime prevention literacy) atau kadang disebut dengan keselamatan diri (personal safety) bisa dimasukkan ke dalam literasi keselamatan (safety literacy). Begitu juga dengan literasi keselamatan di jalan (road safety literacy), literasi keamanan berinternet (digital safety literacy atau online safety literacy), literasi keselamatan di tempat kerja (workplace safety literacy), dan keselamatan yang terkait dengan lokasi spesifik lainnya seperti rumah dan sekolah juga masuk di dalam literasi keselamatan.

Literasi keselamatan bersandar pada fakta bahwa pengetahuan dan pemahaman yang kurang akan kemampuan untuk menjaga keselamatan diri dapat menciptakan potensi kecelakaan atau kejadian yang tidak diinginkan (CBC, 2010, hlm. 3). Literasi keselamatan secara umum adalah tingkatan di mana invidu mempunyai kapasitas untuk memperoleh, memproses, dan memahami informasi dasar yang diperlukan di dalam melakukan kegiatan yang dapat meminimalisasi risiko atau kecelakaan (Howick \& Schmaus, 2018). Beberapa cara bisa dilakukan di dalam pembelajaran literasi keselamatan di 
antaranya dengan refleksi diri (Howick \& Schmaus, 2018), penggunaan media buku cerita bergambar (Ahmad dkk., 2018), studi kasus (Saleh \& Pendley, 2012). Literasi keselamatan ini bisa dalam bentuk kesadaran akan urgensi literasi keselamatan di dunia nyata (literasi keselamatan di sekolah, di rumah, di tempat kerja, di jalan raya), juga di dalam dunia yang kini tersambung dengan dunia digital juga bertalian dengan literasi digital (lih. Sonck dkk., 2011).

Keempat: Literasi gesture (body language literacy) di dalam modul Strategi Literasi dalam Pembelajaran di Sekolah Menengah Pertama (2018, hlm.1-2) disebut dengan "dipelajari untuk mendukung keterpahaman makna teks dan konteks dalam masyarakat multikultural dan konteks khusus para difabel." Dengan penjelasan yang pendek seperti ini, ada dua hal yang tampaknya menjadi sorotan di dalam pembelajaran literasi gestur: komunikasi non-verbal dan komunikasi kepada mereka yang berkebutuhan khusus. Mengenai komunikasi non-verbal, di dalam penelitian bermetode tinjauan pustaka yang dilakukan oleh Bambaeeroo \& Shokrpour (2017, hlm. 53-54) disebutkan bahwa "body language has the power to transfer the attitudes and feelings of people to others and in many cases can be even more effective than verbal messages." Sebab di dalam komunikasi, pesan yang disampaikan lewat kata seringkali terkombinasikan secara kompleks dengan gerak tubuh, posisi berdiri, pandangan mata, dan mimik wajah. Mereka yang mempunyai kemampuan untuk memahami dan mempraktikkan kombinasi komunikasi verbal dengan nonverbal akan lebih efektif di dalam menyampaikan informasi atau mengekspresikan apa yang dipikirkan atau dirasakannya kepada orang lain. Literasi gestur juga termasuk di dalam keahlian yang harus dipelajari di dalam tata pergaulan lintas budaya. Perbedaan budaya kadang menjadikan bahasa tubuh bisa berbeda secara ekstreme antara satu budaya dengan budaya lainnya seperti komunikasi non-verbal yang melibatkan tatapan mata dan kontak fisik (Zhi-peng, 2014, hlm.1031-1032). Sedangkan untuk pembelajaran kemampuan berkomunikasi dengan bahasa isyarat sebagai bagian dari literasi gestur memiliki tujuan selain agar dapat berkomunikasi dengan mereka yang berkebutuhan khusus di dalam interaksi sosial sebagai bagian dari anggota masyarakat dan di dalam kemungkinan interaksi profesional sehingga tidak ada perasaan terkucilkan (Humphries dkk., 2017).

Kelima: Literasi perpustakaan, literasi media, literasi digital, dan literasi informasi saling berkaitan. Di dalam komponen literasi yang dijadikan bagian dari pembelajaran literasi Gerakan Literasi Sekolah (Sutrianto, 2016, hlm. 5-6), disebutkan bahwa literasi perpustakaan meliputi "pemahaman cara membedakan bacaan fiksi dan nonfiksi, memanfaatkan koleksi referensi dan periodikal, memahami Dewey Decimal System sebagai klasifkasi pengetahuan yang memudahkan dalam menggunakan perpustakaan, memahami penggunaan katalog dan pengindeksan, hingga memiliki pengetahuan dalam memahami informasi ketika sedang menyelesaikan sebuah tulisan, penelitian, pekerjaan, atau mengatasi masalah." Kemudian definisi dari literasi media menurut buku Panduan Gerakan Literasi Sekolah (Sutrianto, 2016, hlm. 6) adalah "kemampuan untuk mengetahui berbagai bentuk media yang berbeda, seperti media cetak, media elektronik (media radio, media televisi), media digital (media internet), dan memahami tujuan penggunaannya." Sedangkan definisi dari literasi digital di dalam Peta Jalan Gerakan Literasi Nasional (Ibrahim, 2017, hlm. 32) adalah 
"keterampilan berpikir kritis dan kreatif masyarakat terhadap informasi dan komunikasi sebagai warga global dengan bertanggung jawab dan beretika dalam menggunakan perangkat media digital."

Dari keempat literasi tersebut, payungnya adalah literasi informasi. Literasi informasi didefinisikan oleh Trilling \& Fadel yang dikutip di dalam makalah Wijaya, Sudjimat, \& Nyoto (2016) sebagai "[kemampuan] mengakses informasi secara efektif (sumber informasi) dan efisien (waktunya); mengevaluasi informasi yang akan digunakan secara kritis dan kompeten; menggunakan dan mengelola informasi secara akurat dan efektif untuk mengatasi masalah."

Pengembangan konsep MIL (media and information literacy) UNESCO juga berbicara mengenai sejarah awal literasi informasi melalui literasi perpustakaan sebelum kemudian berkembang kepada literasi media. Literasi informasi dan literasi media bisa saling terintegrasi dalam konteks: 1) pemahaman akan adanya sumber-sumber informasi yang bisa diakses oleh masyarakat, 2) pemahaman bagaimana cara mengakses sumber informasi yang tersedia, 3) kemampuan untuk memilah dan memahami informasi yang bertebaran dari sumber informasi yang ada, 4) pemahaman secara umum mengenai teknologi yang dipakai di dalam produk-produk sumber informasi yang ada (lih. Lee dkk. 2013, hlm. 118-119).

Sementara itu, Chu dkk. (2016) dengan mengadaptasi kategorisasi keterampilan yang harus masuk di dalam pembelajaran sekolah dari P21 menempatkan literasi digital sebagai kategori yang menaungi literasi informasi, literasi media, dan literasi ICT atau TIK (Teknologi Informasi dan Komunikasi).

Literasi informasi (Chu dkk., 2016) diberi definisi sebagai keterampilan mengetahui kapan informasi tertentu dibutuhkan, di mana dapat memperoleh, mengevaluasi, dan menggunakan informasi tersebut secara tepat dan sesuai etika (mis. berselancar di dunia maya untuk mencari informasi tertentu, membaca koran untuk mencari informasi spesifik, menyaksikan televisi untuk mendapatkan informasi tentang kejadian tertentu).

Literasi perpustakaan tidak dibahas di dalam kerangka pembelajaran ini sebab konsep P21 berada dalam konteks dunia digital. Meski demikian, dari definisi tentang literasi informasi tersebut maka literasi perpustakaan dapat masuk di dalamnya.

Untuk literasi visual yang muncul di dalam buku Panduan Gerakan Literasi Sekolah di Sekolah Menengah Atas (Sutrianto, 2016), definisi yang ada mirip dengan definisi literasi informasi tersebut. Sedangkan jika mengikuti pandangan Stokes (2002) mengenai literasi visual, maka istilah ini merujuk pada keterampilan untuk memahami secara kritis pesan yang berwujud simbol atau gambar sebagai pelengkap dari literasi bahasa.

Literasi ICT (Chu dkk., 2016) adalah keterampilan menggunakan teknologi digital, jaringan dan atau alat komunikasi, juga tahu bahwa dengan teknologi digital dan jaringan atau alat komunikasi sebuah informasi dapat diakses, dikontrol, diintegrasikan, dievaluasi, dan diciptakan (mis. menggunakan perangkat lunak tertentu untuk menciptakan diagram kue yang berisi informasi dari data-data yang dikumpulkan). Sedangkan literasi media adalah keterampilan untuk mendekode, mengevaluasi, menganalisis, dan menciptakan media berbentuk cetak atau elektronik (mis. merekam dan mengedit file audio).

Keenam: Literasi data (data literacy) atau literasi data besar (big data literacy) adalah hal yang di dalam kebutuhan pembelajaran kepada siswa di dalam 
menghadapi abad 21. Crusoe (2016) mendefinisikan literasi data sebagai keterampilan untuk memahami data itu apa, bagaimana data dikumpulkan, dianalisis, divisualisasikan, disebarkan, dan memahami bagaimana data dipakai di dalam kegiatan yang bisa menguntungkan pihak tertentu dan potensi kerugian yang terkait keamanan dan kerahasiaan individu menurut takaran budaya masing-masing. Keterampilan ini melingkupi pemahaman yang menempatkan manusia sebagai subjek dari pengumpulan data-data pribadi dari kegiatan mereka di dunia maya. Pembelajaran keterampilan ini menurut Francois \& Monteiro (2018) akan membekali siswa dengan pemahaman bagaimana kehidupan di data-driven society memberikan posisi data dari kehidupan digital sebagai komponen penting.

Ketujuh: Literasi manusia (human literacy) atau sering disebut dengan literasi humanitas bertumpu pada makna kata humanitas di dalam bahasa Indonesia. Humanitas di dalam KBBI mempunyai makna kodrat manusia atau perikemanusiaan. Namun arah literasi manusia yang digaungkan oleh Kemenristek Dikti memiliki penjelasan sebagai "[keterampilan] agar manusia bisa berfungsi dengan baik di lingkungan manusia dan dapat memahami interaksi dengan sesama manusia." (Was, 2018).

Pada kesempatan lainnya, Menristekdikti Mohamad Nasir dalam acara The World Education Forum 2018 menyebutkan kebutuhan tiga literasi baru di dalam pendidikan yaitu: literasi data, literasi teknologi, dan literasi manusia. Nasir kemudian menjelaskan bahwa literasi manusia adalah "[keterampilan] berinteraksi dengan baik, tidak kaku, dapat melakukan pendekatan kemanusiaan dengan melaksanakan komunikasi yang baik dan berbobot, juga harus menguasai desain kreatif dan inovatif" (Nya, 2018).
Apa yang dipaparkan Nasir sejatinya kutipan dari pernyataan di buku karya Aoun (2017, hlm. xviii-xix).

Aoun (2017) menjelaskan bahwa literasi manusia adalah keterampilan yang mampu membuat manusia yang hidup di dunia digital dan robot ini untuk mampu berinteraksi di dalam kehidupan sosial, berkomunikasi dengan manusia lainnya, dan menjadi manusia sesuai kodrat kemanusiaannya. Ia menekankan bahwa kehidupan manusia modern dengan lanskap digitalnya jangan sampai membuat manusia lupa bahwa mereka hidup dan butuh berinteraksi dengan manusia lainnya. Di dalam pembicaraan mengenai literasi manusia ini juga meliputi pembelajaran mengenai etika kemanusiaan yang berbeda dengan robot. Oleh sebab itulah keterampilan untuk dapat bersosialisasi dan berinteraksi dengan baik kepada manusia lain, kemampuan dan kemauan untuk bekerja sama dan berkolaborasi, bertukar ide, bernegosiasi, dan membuat keputusan kolektif perlu untuk dibekalkan kepada siswa. Siswa juga harus dibekali dengan keterampilan untuk menghormati orang lain, menghargai perbedaan, dan saling belajar serta memotivasi untuk memaksimalkan potensi yang dimiliki masing-masing.

Kedelapan: Literasi bahasa (language literacy) hanya sekali disebut di dalam pembicaraan mengenai literasi di Indonesia menurut penelusuran yang telah dilakukan di atas. Namun dari arah pembicaraan literasi bahasa yang menyiratkan kemampuan untuk bersaing secara global (lih. Humas HMP BPPT, 2019) dan kerangka kerja yang mengekor pada P21 maka literasi bahasa yang dimaksud adalah kemampuan menggunakan bahasa internasional seperti bahasa Inggris dengan baik serta turut memahami budaya penuturnya (bdk. P21, 2008). 
Kesembilan: Literasi matematika (mathematical literacy) menurut Gardiner (2004) berbeda dengan literasi numerasi (numeracy literacy). Literasi matematika berkaitan dengan kemampuan melakukan operasi hitung matematika dalam menyelesaikan soal yang bersifat multi-step serta mampu mengaplikasikan dan merefleksikannya di dalam perhitungan, perkiraan, penyederhanaan, dan pengaplikasian matematika di dalam konteks yang berbeda. de Lange (2003) membagi literasi matematika menjadi tiga literasi: literasi spasial, literasi numerasi, dan literasi kuantitatif. Pendapat de Lange ini yang dikutip oleh Sari (2015) di dalam tulisannya yang juga berbicara mengenai literasi matematika sebagaimana sudah dibahas sebelumnya.

Konsep de Lange tentang literasi matematika sedikit berbeda dengan apa yang disodorkan oleh OECD/PISA. Di dalam bab mengenai literasi matematika, OECD/PISA (2015, hlm. 73-74) memetakan literasi matematika ke dalam keterampilan matematika dalam bahasan berkenaan dengan perubahan \& keterkaitan (mis. memahami perubahan angka statistik dan implikasinya), ruang \& bentuk (mis. memahami dimensi bentuk), kuantitas (mis. hitung dan ukur), dan ketidakpastian \& data (mis. memahami peluang dari data yang ada, memprediksi peluang).

Literasi matematika bukan hanya kemampuan mengenali angka dan melakukan operasi hitung akan tetapi kemampuan menggunakan matematika di dalam kehidupan nyata di dalam beragam konteks (de Lange, 2003). Jablonka (2003) juga memiliki pendapat yang tidak begitu berbeda bahwa literasi matematika adalah keterampilan yang dimiliki seseorang di dalam memahami dan menerapkan teori matematika di dalam persoalan-persoalan yang terkait dengan kehidupan riil.
Selain literasi-literasi tersebut, ada literasi yang perlu untuk mulai serius dibicarakan di dalam konteks keindonesiaan. Fokus pada kompetisi antarnegara (skor tes PISA), penciptaan sumber daya manusia yang berkualitas dan mampu bersaing di abad 21 (atau kadang disebut juga dengan era disrupsi, era digital, IR4 atau the $4^{\text {th }}$ industrial revolution), serta penciptaan manusia yang mampu beradaptasi dengan lanskap digital dan robotik tanpa kehilangan keterampilannya di dalam berinteraksi dengan manusia seharusnya tidak melupakan kebutuhan penciptaan manusia di abad 21 yaitu literasi lingkungan dan ekologi.

Literasi lingkungan dan ekologi belum mendapatkan tempat di dalam GLN. Meski sudah ada akademisi yang mulai mendiskusikan literasi ini namun masih di dalam payung pendidikan karakter seperti dilakukan oleh Kusumaningrum (2018). Pembicaraan Kusumaningrum tentang literasi lingkungan berada di bawah payung pendidikan karakter dapat dirujukkan kepada konsep pendidikan karakter. Di dalam konsep pendidikan karakter yang dimulai sejak tahun 2010, ada satu nilai yang menjadi landasan pembentukan karakter yaitu nilai peduli lingkungan. Meski demikian, nilai peduli lingkungan pada pendidikan karakter mendapatkan titik tekan pada pembiasaan perilaku peduli pada lingkungan (lih. Balitbang Kemdiknas, 2011, hlm. 49-51) yang berbeda dengan pembekalan literasi lingkungan.

Literasi lingkungan sejatinya turut menjadi literasi penting yang diangkat oleh P21 dan American Association of Colleges of Teacher Education (AACTE) sebagai bagian dari 21st century interdisciplinary themes (Greenhill, 2010). Menurut North American Association for Environmental Education (dalam McBride dkk., 2013), literasi lingkungan atau environmental literacy adalah kesadaran dan kepedulian terhadap lingkungan dan masalah yang terkait dengannya yang dilandasi pada pengetahuan, keterampilan, dan motivasi dalam rangka menemukan solusi serta mencegah timbulnya masalah baru lainnya. Meski literasi ekologi dengan literasi lingkungan saling sulih ranah dan ada yang 
menganggapnya sebagai bagian dari literasi lingkungan (McBride dkk., 2013) namun literasi ekologi (ecological literacy) lebih menekankan pada pemahaman pada ketergantungan manusia pada atau integrasi dengan alam lingkungan. Seseorang yang berliterasi ekologi akan memahami hubungan sebab akibat di dalam interaksi manusia dengan alam serta mampu membuat keputusan yang berlandaskan pada pemahaman atas proyeksi di masa mendatang terhadap alam lingkungan (McBride dkk., 2013).

Isu lingkungan dan ekologi seharusnya juga mulai dibicarakan secara serius di dalam diskursus literasi di Indonesia. Jika menimbang bahwa Indonesia adalah penyumbang sampah plastik terbesar nomor dua di dunia setelah Cina (Wright \& Waddell, 2017), negara dengan jumlah pengabai perubahan cuaca karena pemanasan global nomor satu di dunia (Renaldi, 2019), dan salah satu penghasil emisi gas rumah kaca terbesar di dunia (Coca, 2018) maka ada urgensi dari literasi lingkungan dan ekologi di dalam kurikulum sekolah di Indonesia. Apalagi berdasarkan penelitian yang dilakukan oleh Parker (2018) di beberapa sekolah di Indonesia, usaha pembelajaran literasi lingkungan dan ekologi masih kurang dan tidak efektif. Apa yang ditemukan oleh Parker (2018) sebenarnya terklarifikasi dari kurang bergaungnya literasi lingkungan dan ekologi di dalam pembicaraan tentang literasi yang perlu dibekalkan kepada siswa di Indonesia.

\section{SIMPULAN}

Gerakan Literasi Nasional (GLN) memulai pembicaraan mengenai literasi di Indonesia. Dari GLN, diskursus mengenai literasi abad 21 di Indonesia berkembang lewat rujukan pada New Vision for Education: Unlocking the Potential of Technology dari World Economic Forum \& Boston Consulting Group (WEF \& BCG). Fokus dari pembicaraan mengenai literasi di Indonesia adalah usaha membekali siswa untuk dapat menghadapi abad 21, atau kadang digunakan istilah lain seperti era disrupsi, era digital, IR4 (the $4^{\text {th }}$ industrial revolution), atau era revolusi industri 4.0.
Bahasan mengenai new vision dan unlocking the potential of technology yang ada di dalam kerangka kerja yang disusun oleh WEF \& BCG mendapatkan arah yang sedikit berbeda di dalam perkembangan isu literasi di Indonesia. Perbedaan pembicaraan tentang implementasi dari kebutuhan literasi baru yang perlu dibekalkan kepada siswa di dalam menghadapi abad 21 terjadi karena adanya penyesuaian dengan infrastruktur yang tersedia di sekolah-sekolah di Indonesia. Diskursus mengenai literasi ini juga kemudian berkembang dengan merujuk pada kerangka kerja pembelajaran abad 21 dari OECD/PISA dan kerangka kerja dari P21 (The Partnership for 21st Century Learning) sebagaimana terdapati di dalam artikel-artikel ilmiah akademisi Indonesia.

Diskursus mengenai literasi dari konsep yang awalnya muncul dari GLN berkembang sangat dinamis. Jenis-jenis literasi yang mengemuka di dalam diskursus mengenai pembelajaran di abad 21 di Indonesia berdasarkan penelitian ini ditemukan ada sembilan belas buah literasi. Ada satu literasi yang belum mendapatkan tempat di dalam GLN meskipun berkelindan dengan konteks Indonesia. Satu literasi yang belum mendapatkan tempat yang layak itu adalah literasi lingkungan dan ekologi.

Berdasarkan simpulan tersebut disarankan agar literasi lingkungan dan ekologi penting untuk mulai digaungkan di dalam pembicaraan mengenai literasi abad 21 menimbang situasi kerusakan lingkungan dan ekologi serta masih rendahnya kesadaran kepedulian lingkungan dan ekologi di Indonesia.

\section{DAFTAR RUJUKAN}

Abdullah, S. (2019, 10 Februari). Kemristekdikti: mahasiswa wajib miliki literasi baru. Antaranews.com, diakses dari: https://www.antaranews.com/berita/7 96565/kemristekdikti-mahasiswawajib-miliki-literasi-baru 
Ahmad, H., Naeem, R., Feroze, A., Zia, N., Shakoor, A., Khan, U. R., \& Mian, A. I. (2018). Teaching children road safety through storybooks: an approach to child health literacy in Pakistan. BMC pediatrics, 18(1), 31. https://doi.org/10.1186/s12887-0180982-5

Amin, M. (2017). Sadar berprofesi guru sains, sadar literasi: Tantangan guru di abad 21. Makalah Prosiding Seminar Nasional III Tahun 2017 "Biologi, Pembelajaran, dan Lingkungan Hidup Perspektif Interdisipliner." Malang: Prodi Pendidikan Biologi-FKIP \& Pusat Studi Lingkungan dan Kependudukan (PSLK) Universitas Muhammadiyah Malang. hlm. 9-20.

Antoro,

B.

(2017).

Gerakan Literasi Sekolah Dari Pucuk Hingga Akar Sebuah Refleksi. Jakarta: Direktorat Jenderal Pendidikan Dasar dan Menengah, Kemendikbud.

Aoun, J. E. (2017). Robot-Proof: Higher Education in the Age of Artificial Intelligence. Cambridge, Massachusetts, London: MIT Press.

Arohman, M., Saefudin, S., \& Priyandoko, D. (2016). Kemampuan literasi sains siswa pada pembelajaran ekosistem. Dalam Proceeding Biology Education Conference: Biology, Science, Enviromental, and Learning (Vol. 13, No. 1, hlm. 9092).

Arp, L. (1994). Library literacy. $R Q$ (Reference and User Services Quarterly), hlm. 158-163.

Balitbang Kemdiknas. (2011). Panduan Pelaksanaan Pendidikan Karakter. Jakarta: Balitbang, Pusat Kurikulum dan Perbukuan, Kemdiknas.

Bambaeeroo, F., \& Shokrpour, N. (2017). The impact of the teachers' non- verbal communication on success in teaching. Journal of advances in medical education \& professionalism, 5(2), 51-59. https://www.ncbi.nlm.nih.gov/pmc/ar ticles/PMC5346168/

Carter, N., Bryant-Lukosius, D., DiCenso, A., Blythe, J., \& Neville, A. J. (2014, September). The use of triangulation in qualitative research. Dalam Oncology nursing forum (Vol. 41, No. 5).

CBC (The Conference Board of Canada). (2010). What You Don't Know Can Hurt You: Literacy's Impact on Workplace Health and Safety. Report July 2010. Ottawa, Canada: The Conference Board of Canada. http://en.copian.ca/library/research/c boc/whatyoudontknow/whatyoudont know.pdf

Chodidjah, I. (2017). Modul dan Pedoman Pelatihan Fasilitator Gerakan Literasi Nasional. Jakarta: Kemendikbud.

Chu S.K.W., Reynolds R.B., Tavares N.J., Notari M., Lee C.W.Y. (2016) Twenty-First Century Skills and Global Education Roadmaps. Dalam 21 st Century Skills Development Through Inquiry-Based Learning. Singapore: Springer.

Coca, N. (2018, 6 Desember). The most important country for the global climate no one is talking about. Vox. Diakses dari https://www.vox.com/energy-andenvironment/.../indonesia-climatechange-deforestation

Crusoe, D. (2016). Data Literacy defined pro populo: To read this article, please provide a little information. The Journal of Community Informatics, 12(3). hlm. 27-46. Diakses dari: http://cijournal.net/index.php/ciej/article/vie $\underline{\mathrm{w} / 1290}$ 
Damayantie, A. R. (2015). Literasi dari Era ke Era. Sasindo: Jurnal Pendidikan Bahasa dan Sastra Indonesia, Vol. 3, No. 1, hlm. 1-10.

de Lange, J. (2003). Mathematics for literacy. Quantitative literacy: Why numeracy matters for schools and colleges, 80, hlm. 75-89.

Dinni, H. N. (2018). HOTS (High Order Thinking Skills) dan Kaitannya dengan Kemampuan Literasi Matematika. Dalam PRISMA, Prosiding Seminar Nasional Matematika, Vol. 1, hlm. 170-176.

Faizah, D.U. dkk. (2016). Panduan Gerakan Literasi Sekolah di Sekolah Dasar. Jakarta: Ditjen Pendidikan Dasar dan Menengah, Kemendikbud.

Flick, U. (2014). Mapping the Field. Dalam Flick, U. (ed.). The SAGE handbook of qualitative data analysis. London, California, New Delhi, Singapore: Sage.

Francois, K. \& Monteiro, C. (2018). Big data literacy. Dalam M. A. Sorto, A. White, \& L. Guyot (Eds.), Looking back, looking forward. Proceedings of the Tenth International Conference on Teaching Statistics (ICOTS10, July, 2018), Kyoto, Japan. Voorburg, The Netherlands: International Statistical Institute.

Gardiner, A. (2004). What is mathematical literacy. ICME-10, 4-11 July 2004, Copenhagen, Denmark.

Greenhill, V. (2010). 21st Century Knowledge and Skills in Educator Preparation. Partnership for 21st century skills. https://eric.ed.gov/?id=ED519336

Harususilo, Y.E. (2018, Desember 4). Pemerintah targetkan sekolah Indonesia berbasis TIK tahun 2023. Kompas - Edukasi. Diakses dari: https://edukasi.kompas.com/read/201 8/12/04/16441841/pemerintahtargetkan-sekolah-indonesiaberbasis-tik-tahun-2023

Hendarman dkk. (2017). Konsep dan Pedoman Penguatan Pendidikan Karakter. Jakarta: Pusat Analisis dan Sinkronisasi Kebijakan, Sekretariat Jenderal, Kemdikbud.

Howick, J., \& Schmaus, D. (2018). Transitioning from the ReflectionBased Safety Literacy Classroom to the Worksite: The Student Experience. Alberta Journal of Educational Research,64(3). https://journalhosting.ucalgary.ca/ind ex.php/ajer/article/view/56337

Humas HMP BPPT. (2019, 24 September). Hadapi Revolusi Industri 4.0, Sistem Pendidikan Perlu Gerakan Literasi Baru. Siaran Pers BPPT SP.No. 101/HMP/HMS/HKH/IX/2019.

Diakses dari: https://www.bppt.go.id/siaranpers/3693-revolusi-industri-4-0-dilingkungan-akademis-sistempendidikan-perlu-gerakan-literasi$\underline{\text { baru }}$

Humphries, T., Kushalnagar, P., Mathur, G., Napoli, D. J., Padden, C., Rathmann, C., \& Smith, S. (2017). Discourses of prejudice in the professions: the case of sign languages. Journal of Medical Ethics, 43(9), 648-652. https://jme.bmj.com/content/medethi cs/43/9/648.full.pdf

Ibrahim, G.A. dkk. (2017). Peta Jalan Gerakan Literasi Nasional. Jakarta: Kemendikbud.

Jablonka, E. (2003) Mathematical Literacy. Dalam Bishop A.J., Clements M.A., Keitel C., Kilpatrick J., Leung F.K.S. (eds) Second International Handbook of Mathematics Education. Springer International Handbooks of Education, vol 10. Springer, Dordrecht. 
https://doi.org/10.1007/978-94-010$\underline{0273-8 \_4}$

Kanbara, S., Ozawa, W., Ishimine, Y., Ngatu, N. R., Nakayama, Y., \& Nojima, S. (2016). Operational definition of disaster risk-reduction literacy. Health Emergency and Disaster Nursing, 3(1), 1-8. https://www.jstage.jst.go.jp/article/he $\underline{\mathrm{dn} / 3 / 1 / 3 \_2014-0016 / \_p d f}$

Keefe, E. B., \& Copeland, S. R. (2011). What is literacy? The power of a definition. Research and practice for persons with severe disabilities, 36(3-4), 92-99.

Kusumaningrum. (2018). Literasi lingkungan dalam kurikulum 2013 dan pembelajaran IPA di SD. Indonesian Journal of Natural Science Education (IJNSE). Vol. 1, No. 2, hlm. 57-64.

Laksono, K. (2018). Strategi Literasi dalam Pembelajaran di Sekolah Menengah Pertama (Edisi II, 2018). Jakarta: Satgas GLS Ditjen Dikdasmen Kementerian Pendidikan dan Kebudayaan.

Lanin, I. (2017, 31 Oktober). Kata "literasi" sudah masuk KBBI V. Salam literasi! [Twitter Post] Diakses dari: https://twitter.com/ivanlanin/status/9 25355667916972032?lang=en

Lee, A., Lau, J., Carbo, T., \& Gendina, N. (2013). Conceptual relationship of information literacy and media literacy in knowledge societies. Paris: UNESCO.

McBride, B. B., Brewer, C. A., Berkowitz, A. R., \& Borrie, W. T. (2013). Environmental literacy, ecological literacy, ecoliteracy: What do we mean and how did we get here?. Ecosphere, 4(5), 1-20. https://esajournals.onlinelibrary.wile y.com/doi/epdf/10.1890/ES1300075.1
Meilanova, D. R. (2019, 7 April). Menristekdikti: Mahasiswa harus kuasai tiga literasi baru. Kabar24. Diakses dari: https://kabar24.bisnis.com/read/2019 0407/79/908779/menristekdiktimahasiswa-harus-kuasai-tiga-literasibaru

Nielsen-Bohlman, L., Panzer, A. M., \& Kindig, D. A. (2004). What Is Health Literacy?. Dalam Health Literacy: A Prescription to End Confusion. National Academies Press (US). hlm. 31-58

https://www.ncbi.nlm.nih.gov/books/ NBK216032/pdf/Bookshelf_NBK21 6032.pdf

Nopilda, L., \& Kristiawan, M. (2018). Gerakan Literasi Sekolah Berbasis Pembelajaran Multiliterasi Sebuah Paradigma Pendidikan Abad Ke21. JMKSP (Jurnal Manajemen, Kepemimpinan, dan Supervisi Pendidikan), 3(2). hlm. 216-231 http://dx.doi.org/10.31851/jmksp.v3i 2.1862

Nya. (2018, 26 Januari). Kemristekdikti Siapkan Literasi Baru Pendidikan Tinggi. Suara Merdeka Cetak Edukasia. Diakses dari https://www.suaramerdeka.com/smce tak/baca/62721/kemristekdiktisiapkan-literasi-baru-pendidikantinggi

OECD/PISA. (2003). Mathematical Literacy. Paris: OECD Publishing. http://www.oecd.org/education/schoo 1/programmeforinternationalstudentas sessmentpisa/33707192.pdf

OECD. (2017). PISA 2015 Assessment and Analytical Framework: Science, Reading, Mathematic, Financial Literacy and Collaborative Problem Solving. Paris: OECD Publishing. DOI: https://doi.org/10.1787/97892642818 $\underline{20 \text {-en }}$ 
P21. (2008). 21 ${ }^{\text {st }}$ Century Skills Map. Massachusetts \& Washington: Partnership for 21st Century Skills. https://files.eric.ed.gov/fulltext/ED51 9502.pdf

P21. (2015). P21 Framework Definitions. The Partnership for 21st Century Learning. hlm. 1-9. Diakses dari: http://static.battelleforkids.org/docum ents/p21/P21_Framework_Definition $\underline{\text { s_New Logo } 2015 \text { 9pgs.pdf }}$

Parker, L. (2018). Environmentalism and education for sustainability in Indonesia. Indonesia and the Malay World, 46:136, 235-

240, DOI: $\underline{10.1080 / 13639811.2018 .1}$ $\underline{519994}$

Permana, F. H. (2015). Pengembangan buku ajar biologi berbasis blended learning sebagai bekal hidup di abad 21 untuk mahasiswa S1 Kimia FMIPA UM. Dalam Prosiding Seminar Nasional Pendidikan Biologi dengan tema "Peran Biologi dan Pendidikan Biologi dalam Menyiapkan Generasi Unggul dan Berdaya Saing Global." Malang: Universitas Muhammadiyah Malang. hlm. 50-61.

Rahayu, S. (2017). Mengoptimalkan aspek literasi dalam pembelajaran kimia abad 21. Dalam Prosiding Seminar Nasional Kimia dengan tema Sinergi Penelitian dan Pembelajaran untuk Mendukung Pengembangan Literasi Kimia pada Era Global. Yogyakarta: Universitas Negeri Yogyakarta.

Renaldi, A. (2019, 15 Mei). Indonesia Is Home to the Most Climate Change Deniers in the World. Vice. Diakses dari

https://www.vice.com/en au/article/a 3x3m8/indonesia-is-home-to-themost-climate-change-deniers-in-theworld

Rizkamariana, F., Diana, S., \& Wulan, A. R. (2019). Penerapan Project Based
Learning untuk Melatih Kemampuan Literasi Tumbuhan Abad 21 pada Siswa SMA. Assimilation: Indonesian Journal of Biology Education, 2(1), 19-23.

Saleh, J. H., \& Pendley, C. C. (2012). From learning from accidents to teaching about accident causation and prevention: Multidisciplinary education and safety literacy for all engineering students. Reliability Engineering \& System Safety, Volume 99, March 2012, hlm. 105-113.

https://doi.org/10.1016/j.ress.2011.10 .016

Sari, R. H. N. (2015). Literasi Matematika: Apa, Mengapa, dan Bagaimana. Dalam Prosiding Seminar Nasional Matematika dan Pendidikan Matematika UNY. Yogyakarta: UNY. hlm. 713-720.

Satgas Gerakan Literasi Sekolah (SGLS). (2016). Buku Saku Gerakan Literasi Sekolah. Jakarta: Ditjen Pendidikan Dasar dan Menengah, Kemendikbud.

Soffel, J. (2016, 10 Maret). What are the 21 st-century skills every student needs? World Economic Forum. Diakses dari: https://www.weforum.org/agenda/20 $\underline{16 / 03 / 21 \text { st-century-skills-future-jobs- }}$ students/

Sonck, N., Livingstone, S., Kuiper, E., \& de Haan, J. (2011). Digital literacy and safety skills. EU Kids Online, London School of Economics \& Political Science, London, UK. http://eprints.lse.ac.uk/33733/

Stokes, S. (2002). Visual literacy in teaching and learning: A literature perspective. Electronic Journal for the integration of Technology in Education, 1(1), 10-19. http://ejite.isu.edu/Volume1No1/pdfs /stokes.pdf 
Sugono dkk. (2008). Kamus Bahasa Indonesia. Jakarta: Pusat Bahasa, Departemen Pendidikan Nasional.

Sutrianto dkk. (2016). Panduan Gerakan Literasi Sekolah di Sekolah Menengah Atas. Jakarta: Direktorat Jenderal Pendidikan Dasar dan Menengah, Kementerian Pendidikan dan Kebudayaan.

Was. (2018, 17 Januari). Era Revolusi Industri 4.0: Perlu Persiapkan Literasi Data, Teknologi dan Sumber Daya Manusia. Berita Ditjen Belmawa. Diakses dari https://belmawa.ristekdikti.go.id/erarevolusi-industri-4-0-perlupersiapkan-literasi-data-teknologidan-sumber-daya-manusia/

WEF \& BCG (World Economic Forum \& The Boston Consulting Group). (2015). New Vision for Education: Unlocking the Potential of Technology. Cologny/Geneve: World Economic Forum. Diakses dari: http://www3.weforum.org/docs/WEF USA NewVisionforEducation Repo $\underline{\mathrm{rt} 2015 . \mathrm{pdf}}$

Wijaya, E. Y., Sudjimat, D. A., \& Nyoto, A. (2016). Transformasi pendidikan abad 21 sebagai tuntutan pengembangan sumber daya manusia di era global. Dalam Prosiding Seminar Nasional Pendidikan Matematika, Vol. 1, No. 26, hlm. 263-278. Malang, Indonesia: Universitas Kanjuruhan Malang.

Wright, T. \& Waddell, S. (2017, 5 September). How can Indonesia win against plastic pollution? Theconversation. Diakses dari https://theconversation.com/how-canindonesia-win-against-plasticpollution-80966

Yuliati, Y. (2017). Literasi Sains dalam Pembelajaran IPA. Jurnal Cakrawala Pendas Vol. 3 No.2 Edisi Juli 2017, hlm. 21-28. http://dx.doi.org/10.31949/jcp.v3i2.5 $\underline{92}$

Zhi-peng, R. (2014). Body language in different cultures. US-Chine Foreign Language,(12), 12, 1029-1033. http://www.davidpublisher.com/Publi c/uploads/Contribute/550928be54286 .pdf 